\title{
Studies on Wound Healing Activity of Heliotropium indicum Linn. Leaves on Rats
}

\author{
G. K. Dash ${ }^{1}$ and P. N. Murthy ${ }^{2}$ \\ ${ }^{1}$ Institute of Pharmacy and Technology, Salipur, Cuttack District, Odisha 754202, India \\ ${ }^{2}$ Royal College of Pharmacy and Health Sciences, Andha Pasara Road, Berhampur, Odisha 760002, India
}

Correspondence should be addressed to G. K. Dash, gk_dash@rediffmail.com

Received 15 January 2011; Accepted 24 February 2011

Academic Editor: F. J. Miranda

Copyright (c) 2011 G. K. Dash and P. N. Murthy. This is an open access article distributed under the Creative Commons Attribution License, which permits unrestricted use, distribution, and reproduction in any medium, provided the original work is properly cited.

\begin{abstract}
The petroleum ether, chloroform, methanol, and aqueous extracts of Heliotropium indicum Linn. (Family: Boraginaceae) were separately evaluated for their wound healing activity in rats using excision (normal and infected), incision, and dead space wound models. The effects of test samples on the rate of wound healing were assessed by the rate of wound closure, period of epithelialisation, wound breaking strength, weights of the granulation tissue, determination of hydroxyproline, super oxide dismutase (SOD), catalase, and histopathology of the granulation tissues. Nitrofurazone $(0.2 \% \mathrm{w} / \mathrm{w})$ in simple ointment I. P. was used as reference standard for the activity comparison. The results revealed significant promotion of wound healing with both methanol and aqueous extracts with more promising activity with the methanol extract compared to other extracts under study. In the wound infection model (with $S$. aureus and P. aeruginosa), the methanol extract showed significant healing activity similar to the reference standard nitrofurazone. Significant increase in the granulation tissue weight, increased hydroxyproline content, and increased activity of SOD and catalase level with the animals treated with methanol extract in dead space wound model further augmented the wound healing potential of $H$. indicum. The present work substantiates its validity of the folklore use.
\end{abstract}

\section{Introduction}

Wound healing is the process of repair that follows injury to the skin and other soft tissues. It involves a complex series of interactions between different cell types, cytokine mediators, and the extracellular matrix. Each phase of normal wound healing, namely, hemostasis, inflammation, proliferation and remodeling is distinct although the wound healing process is continuous, with each phase overlapping the next. Several medicinal plants have been used since time immemorial for treatment of cuts, wounds, and burns and showed promising effects. Some very common plants like Aloe vera, Azadirachta indica, Carica papaya, Celosia argentea, Centella asiatica, Cinnamomum zeylanicum, Curcuma longa, Nelumbo nucifera, Ocimum sanctum, Phyllanthus emblica, Plumbago zeylanica, Pterocarpus santalinus, Terminalia arjuna, and Terminalia chebula have been extensively reported in Ayurveda, Siddha, and Unani systems of medicines for their wound healing potential [1].
Heliotropium indicum Linn. (Family: Boraginaceae) is a coarse foetid herb, up to $2 \mathrm{ft}$. high, found throughout India in sunny localities, on waste lands, and anthropogenic habitats, widely considered as a weed of fields [2-4]. The plant is reported to be highly valued in the folklore medicine and is believed to be useful in treating malaria, abdominal pain, fever, dermatitis, venereal diseases, insect bites, menstrual disorder, urticaria, and sore throat [5-9]. The plant decoction is considered as diuretic and remedy for the treatment of kidney stone $[10,11]$. The leaf paste is applied externally to cure rheumatism and skin infections $[12,13]$. The various tribes of Phulbani district of Odisha use the leaf paste over fresh cuts and wounds and claim for its promising activity.

Several pyrolizidine alkaloids, namely, echinatine, heleurine, heliotriene, lasiocarpine, indicine, indicine N-oxide, retronicine, cynoglossine, and supinine have been reported from the plant [14-19]. 
Reports on the biological activity of the plant are many. Different extracts of $H$. indicum have been studied for possible biological activities in various animal models and reported to possess significant anti-inflammatory, diuretic, abortifacient, wound healing and antitumor activities [2023]. The active principle responsible for the antitumor activity is reported to be indicine $\mathrm{N}$-oxide [24]. The aqueous extract of the leaves is reported to possess strong uterine stimulant effect $[25,26]$. Earlier reports on wound healing activity of the plant have been reported on the basis of only preliminary animal models like excision and incision wound models. The present study was undertaken to provide an indepth study on wound healing activity of the leaves using all possible models and to provide a scientific support to its use in the folklore medicines for treating wound infection.

\section{Materials and Methods}

2.1. Plant Material. The plant material (leaves) were collected from the forests of Phulbani district of Odisha during November 2009 and authenticated. The leaves were washed, shade dried and pulverized to coarse powder. The powdered leaves $(500 \mathrm{~g})$ was successively extracted with petroleum ether $\left(40-60^{\circ} \mathrm{C}\right)$, chloroform, methanol and water for $48 \mathrm{~h}$ in a soxhlet extractor. Following extraction, the liquid extracts were concentrated under vacuum to yield dry extracts. Standard methods [27, 28] were used for preliminary phytochemical screening of the different extracts to know the nature of phytoconstituents present within them.

2.2. Animals. Healthy Wistar albino rats (150-250 g) of either sex and of approximately the same age were used for the study. They were individually housed, maintained in clean polypropylene cages and fed with commercially pellet diet (M/s Hindustan Lever Ltd., Mumbai) and water ad libitum. The experimental protocols were subjected to scrutiny of Institutional Animal Ethics Committee for experimental clearance (no. 1025/C/07/CPCSEA).

2.3. Wound Healing Activity. The selected extracts of $H$. indicum were separately evaluated for their wound healing activity in rats using excision (normal and infected), incision and dead space wound models. The effects of test samples on the rate of wound healing were assessed by the rate of wound closure, period of epithelialisation, wound breaking strength, weights of the granulation tissue, determination of hydroxyproline, super oxide dismutase (SOD), catalase and histopathology of the granulation tissue. Nitrofurazone $(0.2 \% \mathrm{w} / \mathrm{w})$ in simple ointment I. P. was used as reference standard for the activity comparison. The test extracts were mixed with simple ointment I. P. $(10 \% \mathrm{w} / \mathrm{w})$ and used in the excision and incision models. For the dead space wound model, the methanol extract was suspended in water and used.

2.4. Excision Wound Model (Normal Wounds). Animals were anesthetized prior to and during creation of the wounds, with $1 \mathrm{~mL}$ of intravenous ketamine hydrochloride
$(10 \mathrm{mg} / \mathrm{kg})$. The rats were inflicted with excision wounds as described by Morton and Malone [29] and suggested by Kamath et al. [30]. An impression was made on the dorsal thoracic region $1 \mathrm{~cm}$ away from vertebral column and $5 \mathrm{~cm}$ away from ear on the anaesthetized rat. The dorsal fur of the animals was shaved with an electric clipper and the anticipated area of the wound to be created was outlined on the back of the animals with methylene blue using a circular stainless steel stencil. A full thickness of the excision wound of circular area of $500 \mathrm{~mm}^{2}$ and $2 \mathrm{~mm}$ depth was created along the markings using toothed forceps, scalpel and pointed scissors. Haemostasis was achieved by blotting the wound with cotton swab soaked in normal saline. The entire wound was left open [31]. All surgical procedures were performed under aseptic conditions.

The control group animals (Group I) were treated with the vehicle (simple ointment I. P.), the positive control (Group II) was applied with $0.2 \% \mathrm{w} / \mathrm{w}$ nitrofurazone in simple ointment I. P. Other groups of animals were treated with the following: petroleum ether, chloroform, methanol or aqueous extracts of $H$. indicum at a concentration of $10 \%$ w/w in simple ointment I. P. in a similar manner.

The wound closure rate was assessed by tracing the wound on days $1,4,6,8,11,14$, and 16 after wounding days using transparent paper and a permanent marker. The wound areas recorded were measured using graph paper [4]. The percentage of wound healing was calculated of original wound size for each animal of group on predetermined days that is, $1,4,6,8,11,14$ and 16 days post-wounding for final analysis of results. Changes in wound area were calculated, giving an indication of the rate of wound contraction [5]. The period of epithelialisation was calculated as the number of days required for falling of the dead tissue remnants without any residual raw wound. The results are tabulated in Table 2.

2.5. Incision Wound Model. The rats were anaesthetized prior to and during creation of the wounds, with $1 \mathrm{~mL}$ of intravenous ketamine hydrochloride $(10 \mathrm{mg} / \mathrm{kg})$. The dorsal fur of the animals was shaved with an electric clipper. A longitudinal paravertebral incision of $6 \mathrm{~cm}$ long was made through the skin and cutaneous tissue on the back as described by Ehrlich and Hunt [32]. After the incision, the parted skin was sutured $1 \mathrm{~cm}$ apart using a surgical thread and curved needle. The wounds were left undressed [33]. Extracts were topically applied to the wound once a day. The sutures were removed on 8 th post wound day and continued the application of the extract. The wound breaking strength [34] was measured on the 10th day evening after the last application. The results are tabulated in Table 3.

The healing tissues obtained on the 10th day from all four groups of animals of the incision wound model were processed for histological study $[35,36]$.

2.6. Excision Wound Model (Infected Wounds). The results of the excision and incision wound models revealed that the methanol extract of $H$. indicum possesses comparatively better wound healing activity compared to other test extracts 
TABLE 1: Preliminary phytochemical screening of different extracts of $H$. indicum leaves.

\begin{tabular}{lcccccccccc}
\hline Extract & Alkaloids & Carbohydrates & Glycosides & $\begin{array}{c}\text { Gums and } \\
\text { mucilages }\end{array}$ & $\begin{array}{c}\text { Proteins } \\
\text { and amino } \\
\text { acids }\end{array}$ & $\begin{array}{c}\text { Tannins and } \\
\text { phenolic } \\
\text { compounds }\end{array}$ & $\begin{array}{c}\text { Steroids } \\
\text { and } \\
\text { sterols }\end{array}$ & Triterpenoids Saponins Flavonoids \\
\hline Pet. Ether & - & - & - & - & - & - & + & + & + & - \\
Chloroform & + & - & - & - & - & - & + & + & - \\
Methanol & + & - & - & - & + & + & - & - & + \\
Aqueous & - & + & - & + & + & + & - & - & + \\
\hline
\end{tabular}

(+): Present; (-): Absent.

TABLE 2: Effect of various extracts of $H$. indicum leaves on percentage (\%) wound closure (excision wound model).

\begin{tabular}{|c|c|c|c|c|c|c|c|c|}
\hline \multirow{2}{*}{ Group } & \multirow{2}{*}{ Treatment } & \multicolumn{6}{|c|}{ Percentage (\%) wound closure } & \multirow{2}{*}{$\begin{array}{l}\text { Period of } \\
\text { epithelialization } \\
\text { (No. of days) }\end{array}$} \\
\hline & & 4th days & 6th days & 8th days & 11th days & 14th days & 16th days & \\
\hline I & Control & $23.52 \pm 1.21$ & $37.72 \pm 1.58$ & $51.92 \pm 1.71$ & $71.28 \pm 2.23$ & $79.24 \pm 1.18$ & $83.56 \pm 1.03$ & $23.16 \pm 0.71$ \\
\hline II & $\begin{array}{c}\text { Nitrofurazone } \\
(0.2 \% \mathrm{w} / \mathrm{w})\end{array}$ & $48.53 \pm 2.87^{*}$ & $74.23 \pm 3.32^{* *}$ & $84.8 \pm 1.26^{* *}$ & $96.54 \pm 1.29^{* *}$ & $100 \pm 00^{* *}$ & - & $13.5 \pm 1.54^{* *}$ \\
\hline III & $\begin{array}{l}\text { Pet ether } \\
\text { extract }\end{array}$ & $22.15 \pm 1.75$ & $38.73 \pm 2.16$ & $44.70 \pm 3.25$ & $70.58 \pm 1.88$ & $79.69 \pm 1.22$ & $83.88 \pm 2.01$ & $20.5 \pm 1.33$ \\
\hline IV & $\begin{array}{c}\text { Chloroform } \\
\text { extract }\end{array}$ & $24.19 \pm 1.03$ & $44.41 \pm 1.22$ & $61.88 \pm 1.83$ & $75.68 \pm 2.31$ & $81.26 \pm 1.65$ & $85.80 \pm 1.43$ & 19. $\pm 0.91^{*}$ \\
\hline $\mathrm{V}$ & $\begin{array}{c}\text { Methanol } \\
\text { extract }\end{array}$ & $28.88 \pm 1.95$ & $48.34 \pm 1.86^{*}$ & $79.78 \pm 1.91^{*}$ & $86.37 \pm 1.01^{* *}$ & $97.76 \pm 2.22^{* *}$ & $100 \pm 00^{* *}$ & $16.23 \pm 0.98^{* *}$ \\
\hline VI & $\begin{array}{l}\text { Aqueous } \\
\text { Extract }\end{array}$ & $29.23 \pm 1.65$ & $48.01 \pm 2.01^{*}$ & $65.28 \pm 2.83^{*}$ & $77.25 \pm 1.11^{*}$ & $90.42 \pm 1.71^{* *}$ & $93.7 \pm 1.22$ & $18.5 \pm 0.77^{*}$ \\
\hline
\end{tabular}

Values are expressed as mean \pm S.E. $(n=6)$. All columns are significant using ANOVA.

${ }^{*} P<.05,{ }^{*} P<.01$ when compared to control; Dunnet's $t$-test.

TABLE 3: Effect of various extracts of $H$. indicum leaves on wound breaking strength (incision wound model).

\begin{tabular}{lcc}
\hline Group & Treatment & Breaking strength $(\mathrm{g})$ \\
\hline I & Control & $327.5 \pm 16.58$ \\
II & Nitrofurazone $(0.2 \% \mathrm{w} / \mathrm{w})$ & $491.21 \pm 16.26^{* *}$ \\
III & Pet ether extract & $336.23 \pm 15.64$ \\
IV & Chloroform extract & $347 \pm 14.63$ \\
V & Methanol extract & $478.55 \pm 12.63^{* *}$ \\
VI & Aqueous extract & $378.63 \pm 18.02^{*}$ \\
\hline
\end{tabular}

Values are expressed as mean \pm S.E. $(n=6)$. All columns are significant using ANOVA.

${ }^{*} P<.05,{ }^{* *} P<.01$ when compared to control; Dunnet's $t$-test.

under study. Therefore, infected wound model was separately performed on the methanol extract of $H$. indicum taking Staphylococcus aureus and Pseudomonas aeruginosa as the infecting bacteria.

The methods of Abo et al. [37] and Odimegwu et al. [38] was followed. The selected rats were divided into three groups, each containing 6 animals. A round seal of $20 \mathrm{~mm}$ diameter was impressed on the two sides of the central trunk depilated and sterilized with ethanol. Excision wound was inflicted on the rats as described earlier. Full skin thickness was excised from the marked area to get a wound measuring about $314 \mathrm{~mm}^{2}$. After achieving complete haemostasis by blotting the wound with cotton swab soaked in warm saline, the wound of each animal was inoculated separately with an overnight ( $18 \mathrm{~h}$ old) S. aureus and P. aeruginosa cultures. The animals were placed singly in individual cages. The infected wounds on each animal of the control group were treated topically with simple ointment I. P. Other groups of animals were treated separately with one of the following: $0.2 \% \mathrm{w} / \mathrm{w}$ nitrofurazone or $10 \% \mathrm{w} / \mathrm{w}$ methanol extract of $\mathrm{H}$. indicum in simple ointment I. P. in a similar manner.

Treatments of the infected wounds commenced on the 3rd day to allow for the establishment of the infection on the wound. The wound area was measured with a transparent graph paper on $1,4,6,8,11,14$ and 16 day. Wound contraction was calculated as a percentage of the original wound size. The results are presented in Tables 4 and 5.

2.7. Acute Oral Toxicity Studies. Acute oral toxicity studies of the extracts were carried out as per the OECD guidelines, draft guidelines 423 [39]. Different groups of animals each 
TABLE 4: Screening for wound healing activity of the methanol extracts of the selected plants (excision wound model) by inoculated with Stapphylococcus aureus.

\begin{tabular}{|c|c|c|c|c|c|c|c|c|}
\hline \multirow{2}{*}{ Group } & \multirow{2}{*}{ Treatment } & \multicolumn{6}{|c|}{ Percentage (\%) wound closure } & \multirow{2}{*}{$\begin{array}{l}\text { Period of } \\
\text { epithelialization } \\
\text { (no. of days) }\end{array}$} \\
\hline & & 4th days & 6th days & 8th days & 11th days & 14th days & 16th days & \\
\hline I & Control & $10 \pm 1.29$ & $19.5 \pm 2.34$ & $34 \pm 3.83$ & $44.5 \pm 5.75$ & $52 \pm 4.53$ & $58.4 \pm 5.85$ & $29.12 \pm 2.65$ \\
\hline II & $\begin{array}{l}\text { Nitrofurazone } \\
(0.2 \% \mathrm{w} / \mathrm{w})\end{array}$ & $15.83 \pm 6.21$ & $36.33 \pm 2.98^{* *}$ & $59.5 \pm 4.48^{* *}$ & $76.33 \pm 4.91^{* *}$ & $90.5 \pm 3.39^{* *}$ & $97.33 \pm 1.97^{* *}$ & $18.03 \pm 1.23^{* *}$ \\
\hline III & $\begin{array}{c}\text { Methanol } \\
\text { extract (HI) }\end{array}$ & $15.5 \pm 1.4$ & $33.5 \pm 3.6^{* *}$ & $57.66 \pm 3.84^{* *}$ & $63.16 \pm 3.89^{* *}$ & $77.66 \pm 3.71^{* *}$ & $93 \pm 2.25^{* *}$ & $19.11 \pm 0.88^{* *}$ \\
\hline
\end{tabular}

Values are expressed as mean \pm S.E. $(n=6)$. All columns are significant using ANOVA.

${ }^{*} P<.05,{ }^{*} P<.01$ when compared to control; Dunnet's $t$-test. (HI-H. indicum).

TABLE 5: Screening for wound healing activity of the methanol extract of the selected plants (excision wound model) by inoculated with $P$. aeruginosa.

\begin{tabular}{|c|c|c|c|c|c|c|c|c|}
\hline \multirow{2}{*}{ Group } & \multirow{2}{*}{ Treatment } & \multicolumn{6}{|c|}{ Percentage (\%) wound closure } & \multirow{2}{*}{$\begin{array}{l}\text { Period of } \\
\text { epithelialization } \\
\text { (no. of days) }\end{array}$} \\
\hline & & 4th days & 6th days & 8th days & 11 th days & 14 th days & 16th days & \\
\hline I & Control & $8.22 \pm 1.81$ & $15.6 \pm 1.22$ & $21.08 \pm 2.71$ & $32.41 \pm 3.33$ & $46.61 \pm 3.85$ & $51.13 \pm 2.15$ & $30.33 \pm 2.23$ \\
\hline II & $\begin{array}{l}\text { Nitrofurazone } \\
(0.2 \% \mathrm{w} / \mathrm{w})\end{array}$ & $14.21 \pm 1.09$ & $25.73 \pm 3.81^{*}$ & $39.43 \pm 2.22^{* *}$ & $57.63 \pm 3.11^{* *}$ & $78.56 \pm 2.48^{* *}$ & $92.53 \pm 3.25^{* *}$ & $18.73 \pm 1.81^{* *}$ \\
\hline III & $\begin{array}{l}\text { Methanol } \\
\text { extract (HI) }\end{array}$ & $12.5 \pm 1.25$ & $21.5 \pm 2.81$ & $32.26 \pm 2.14^{*}$ & $49.6 \pm 2.18^{* *}$ & $70.22 \pm 3.81^{* *}$ & $84.26 \pm 2.55^{* *}$ & $20.10 \pm 0.48^{*}$ \\
\hline
\end{tabular}

Values are expressed as mean \pm S.E. $(n=6)$. All columns are significant using ANOVA.

${ }^{*} P<.05,{ }^{*} P<.01$ when compared to control; Dunnet's $t$-test. (HI-H. indicum).

containing three female rats $(180-210 \mathrm{~g})$ received $H$. indicum methanol extract suspended in water separately at doses of 300,600 , and $2000 \mathrm{mg} / \mathrm{kg}$ orally by gavage. Animals were observed individually after dosing once during the first 30 minutes, periodically during the first 24 hours, with special attention given during the first 4 hours and daily thereafter, for a total of 14 days. Observations included changes in skin and fur, eyes and mucous membranes, and respiratory and behaviour pattern. A special attention was directed to observations of tremors, convulsions, salivation, diarrhea, lethargy, sleep and coma. The change in body weight, food and water intake was recorded at two days interval.

There was no mortality or morbidity observed in animals through the 14-day period following single oral administration at all selected dose levels of the methanol extract of $H$. indicum. Morphological characteristics (fur, skin, eyes, and nose) appeared normal. No tremors, convulsion, salivation, diarrhea, lethargy, or unusual behaviours such as self mutilation walking backward and were observed; gait and posture, reactivity to handling or sensory stimuli, and grip strength were all normal. There was no significant difference in body weights between control and treatment groups.
2.8. Dead Space Wound Model. Dead space wounds were created by implanting two preweighed sterilized polypropylene tube $(2.5$ length $\times 0.25 \mathrm{~cm}$ diameter $)$ beneath the dorsal paravertebral skin of the anaesthetized rats [40]. The animals were randomly divided into two groups of six each. The control group animals were provided with plain drinking water, and the other group rats were separately administered with the methanol extract of $H$. indicum at a dose of $100 \mathrm{mg} / \mathrm{kg}$ daily. On the 10th post-wounding day, the granulation tissue formed on the implanted tubes was carefully detached from surfaces of the tubes. The wet weight of the granulation tissue collected was noted. The tissue samples were dried at $60^{\circ} \mathrm{C}$ for $12 \mathrm{~h}$ and weighed to determine the dry granulation tissue weight. The results are depicted in Table 6.

The dried tissue $(50 \mathrm{mg}$ ) was added to $1 \mathrm{~mL} 6 \mathrm{M} \mathrm{HCl}$ and kept at $110^{\circ} \mathrm{C}$ for $24 \mathrm{~h}$. The neutralized acid hydrolysate of the dry tissue was used for the determination of hydroxyproline [41]. Part of the granulation tissue was collected in phosphate-buffered saline for the estimation of antioxidant enzymes superoxide dismutase (SOD) [42] and catalase [43].

2.9. Histological Studies. For histological studies, pieces of granulation tissues from incision wound model were fixed 
TABLE 6: Wound healing effects of the methanol extracts of $H$. indicum in dead space wound model, hydroxyproline content in granulation tissues and the level of antioxidant enzymes in granuloma tissue.

\begin{tabular}{lccccc}
\hline Treatment & $\begin{array}{c}\text { Wet tissue weight } \\
(\mathrm{mg})\end{array}$ & $\begin{array}{c}\text { Dry tissue weight } \\
(\mathrm{mg})\end{array}$ & $\begin{array}{c}\text { Concentration of } \\
\text { hydroxyproline } \\
(\mathrm{mg} / 100 \mathrm{~g} \text { dry tissue) }\end{array}$ & $\begin{array}{c}\text { Superoxide dismutase } \\
\text { (units/mg) }\end{array}$ & $\begin{array}{c}\text { Catalase } \\
(\mathrm{unit} / \mathrm{mg})\end{array}$ \\
\hline $\begin{array}{l}\text { Control } \\
\begin{array}{l}\text { Methanol } \\
\text { extract (HI) }\end{array}\end{array}$ & $91.36 \pm 2.37$ & $42.22 \pm 2.07$ & $2933.33 \pm 326.60$ & $0.117 \pm 0.011$ & $0.08 \pm 0.013$ \\
\hline
\end{tabular}

Values are expressed as mean \pm S.E. $(n=6)$.

${ }^{*} P<.05, * * P<.01$ when compared to control; Dunnet's $t$-test. (HI-H. indicum).

in $10 \%$ neutral formalin solution for $24 \mathrm{~h}$ and dehydrated with a sequence of ethanol-xylene series of solutions. The materials were filtered and embedded with paraffin (40$60^{\circ} \mathrm{C}$ ). Microtome sections were taken at $10 \mu$ thickness. The sections were processed in alcohol-xylene series and stained with hemotoxylin-eosin dye. The histological changes were observed under a microscope. Photographs were taken from each slide and presented in Figure 1.

2.10. Statistical Analysis. The data obtained in the studies were subjected to one way of analysis of variance (ANOVA) for determining the significant difference. The inter group significance was analyzed using Dunnet's $t$-test. A $P$ value < .05 was considered to be significant. All the values were expressed as Mean \pm SEM.

\section{Results}

The preliminary phytochemical screening of $H$. indicum leaf extracts showed presence of steroids and sterols, triterpenoids, alkaloids, flavonoids, saponins, tannins and phenolic substances, gums and mucilages, carbohydrates, and proteins, respectively, in different extracts (Table 1).

The results of wound healing effects of $H$. indicum showed significant promotion of wound healing activity with both aqueous and methanol extracts in the excision and incision wound models. In excision wound model, the mean percentage closure of wound area was calculated on the $4,6,8,11,14$ and 16 post-wounding days as shown in Table 2. The methanol extract-treated animals showed faster epithelialisation of wound than the animals treated with aqueous leaf extract. The percentage of wound closure was $100 \pm 00$ in the case of standard drug nitrofurazone on 14th day of treatment, where as the methanol extract demonstrated similar effects on 16th day. But the petroleum ether and chloroform extracts did not reveal significant activity. The period of epithelialization was 16.23 \pm 0.98 days for the methanol extract treated group of animals as against $13.5 \pm 1.54$ for the standards drug-treated group.

In incision wound model (Table 3), the methanol and aqueous extract treated animals showed significant increase in breaking strength $(478.55 \pm 12.63$ and $378.63 \pm 18.02$ resp.), when compared to the control $(327.5 \pm 16.58)$. The mean breaking strength was also significant in animals treated with standard drug nitrofurazone $(491.21 \pm 16.26)$ whereas the other extracts failed to produce significant effects. The methanol extract showed better activity $(P<.01)$ than the aqueous extract $(P<.05)$.

The results of the excision and incision wound models revealed that the methanol extracts of $H$. indicum possess better wound healing activity compared to other test extracts under study, so the work was further extended to investigate its activity on infection of wounds model. In the wound infection model (with $S$. aureus), the methanol extract showed significant activity $(P<.01)$ from 6 th day and throughout the experiment similar to the reference standard nitrofurazone (Table 4). But the wounds infected with $P$. aeruginosa, significant activity was observed from 8 th day (Table 5).

In dead space wound model (Table 6), the methanol extract-treated animals showed significant increase in dry weight of granulation tissue. Estimation of hydroxyproline content in the granulation tissue revealed that the animal groups treated with methanol extract had high hydroxyproline content (7085.82 \pm 687.47$)$ as against the control group $(2933.33 \pm 326.60)$. In case of the antioxidant parameters, rats treated with the methanol extracts of $H$. indicum showed significant increase in the activity of SOD and catalase level in granulation tissue compared with controls.

The histological profiles of granulation tissue of control animals (Figure 1(a)) showed more macrophages and less collagenation. The sections of granulation tissue of methanol and aqueous extract-treated animals showed the sign of tissue repair with increased collagen formation (Figures $1(\mathrm{e})$ and $1(\mathrm{f})$ ) and less macrophages. Whereas, in the petroleum ether and chloroform extract-treated animals the healing activity was comparatively lesser with moderate collagenation and retention of the macrophages (Figures $1(c)$ and 1(d)). The nitrofurazone treated group of animals also revealed increased collagen fibers with few macrophages (Figure 1(b)).

\section{Discussion}

The results of the present study revealed that animals treated with methanol and aqueous extracts of $H$. indicum showed faster rate of epithelialization in excision wound model compared to other extracts under study. The chloroform extract of the selected plants also produced promising results, but the effects are seen to be of lesser extent than the corresponding methanol and aqueous extracts. The petroleum 


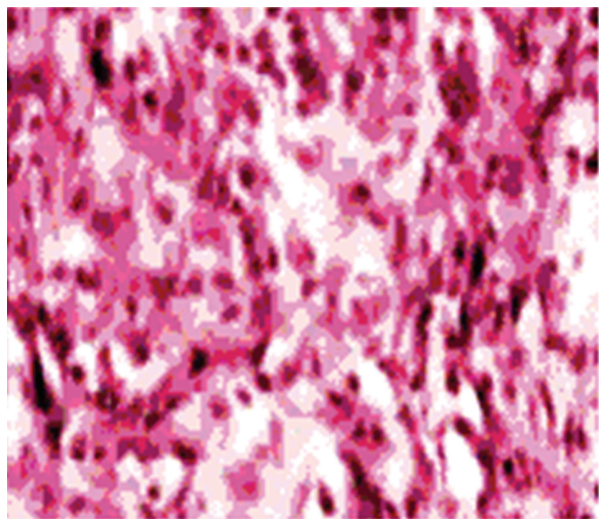

(a)

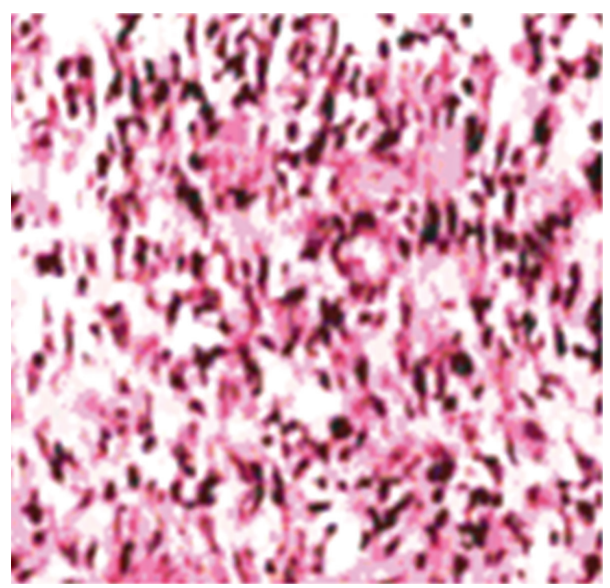

(c)

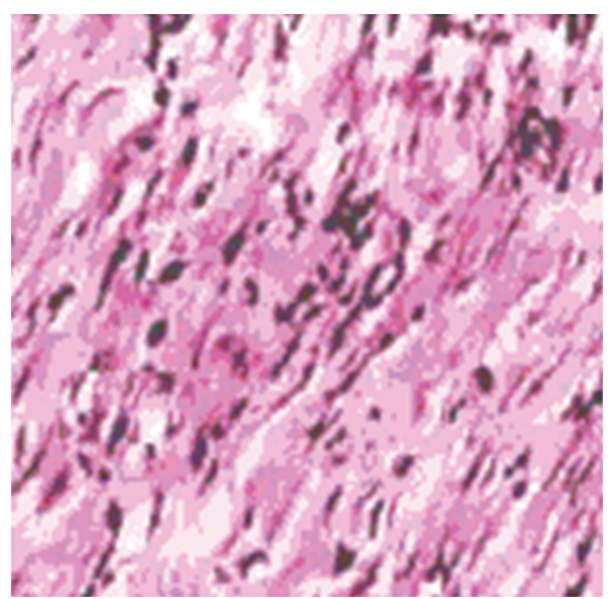

(e)

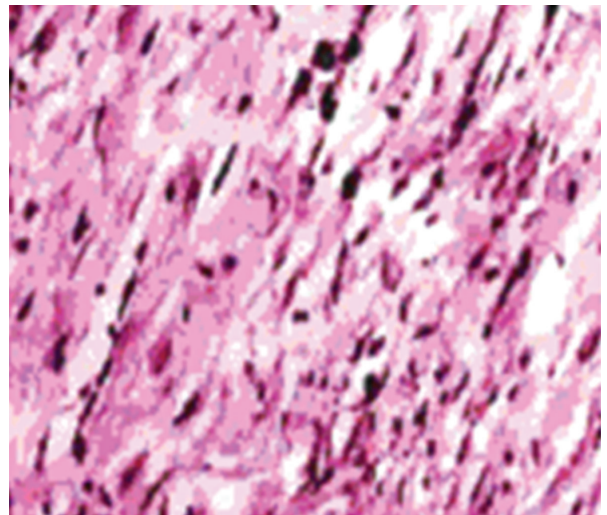

(b)

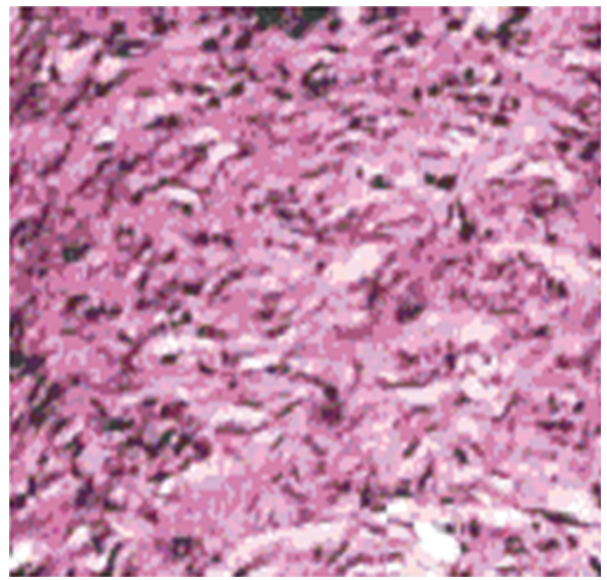

(d)

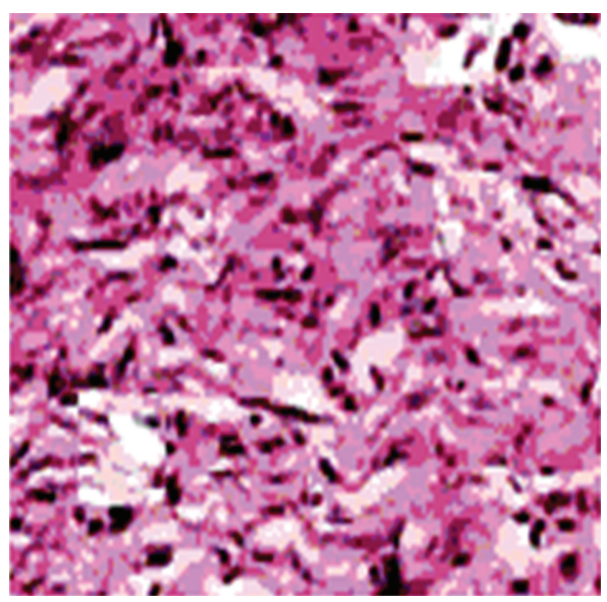

(f)

FIGURE 1: Histology of granulation tissue of H. indicum. (a) Granulation tissue of Group I animal (control) showing with less collagen and more macrophages. (b) Granulation tissue of Group II (standard) animal showing significant collagenation, lesser fibroblasts and capillaries. (c) Section of granulation tissue of group III animal (pet-ether extract of $H$. indicum) showing with less collagenation with less monocytes, fibroblasts and capillaries. (d) Granulation tissue of Group IV (chloroform extract of H. indicum) animal showing with moderate collagen and moderate macrophages. (e) Histological section of granulation tissue of Group V animal treated with methanol extract of $H$. indicum showing significant increased collagenation, few macrophages and capillaries. (f) Section of granulation tissue of Group VI (aqueous extract of $H$. indicum) animal showing moderate collagenation with less macrophages, fibroblasts, and capillaries. 
ether extract of all the plant materials did not produce significant results. The wound healing effects of the chloroform, methanol, and aqueous extracts may be attributed to the presence of phytoconstituents like alkaloids, triterpenoids, tannins and flavonoids in the extracts which are known to promote the wound healing process mainly due to their antimicrobial property. Flavonoids and triterpenoids are also known to promote the wound healing process mainly due to their astringent and antimicrobial property, which seems to be responsible for wound contraction and increased rate of epithelialisation [44-46]. In the present laboratory all the surgical interventions were carried out under sterile conditions and animals were closely observed for any infection; those which showed signs of infection were separated and excluded from the study. This is very important and researchers proved that the control microbial infection is necessary for better wound healing and its management $[47,48]$.

Increase in skin breaking strength and tissue breaking strength in incision and dead space wound model respectively indicated enhanced collagen maturation. Increase in the granulation tissue dry weight and hydroxyproline content indicated the high collagen turnover which may be due to the activity of some phytoconstituents like flavonoids which are known to reduce lipid peroxidation not only by preventing or slowing the onset of cell necrosis but also by improving vascularity. Hence, any drug that inhibits lipid peroxidation is believed to increase the viability of collagen fibrils by increasing the strength of collagen fibers, by increasing the circulation, by preventing the cell damage and by promoting the DNA synthesis [49]. Hence, the wound healing promoting activity of $H$. indicum may also be attributed to the antioxidant and antibacterial potency of the active constituents present in them.

Thus, wound healing property of the methanol and aqueous extracts may be attributed to the phytoconstituents they contain, which may be either due to their individual or additive effect that fastens the process of wound healing. The methanol extracts of each selected plant materials were found to possess better wound healing property over other extracts. At this stage, it is difficult to say which component(s) of the extracts are responsible for the wound healing activity. However, further phytochemical studies are needed to isolate the active compound(s) responsible for these pharmacological activities.

\section{References}

[1] B. Kumar, M. Vijayakumar, R. Govindarajan, and P. Pushpangadan, "Ethnopharmacological approaches to wound healingExploring medicinal plants of India," Journal of Ethnopharmacology, vol. 114, no. 2, pp. 103-113, 2007.

[2] Y. R. Chadha, The Wealth of India, C. S. I. R., New Delhi, India, 1985.

[3] K. R. Kirtikar and B. D. Basu, Indian Medicinal Plants: Bishen Singh Mahendrapal Singh, Klewer, Dehradun, India, 1994.

[4] R. Stewart, "Herbalism: most common form of medicine available," The Eastern Pharmacist, vol. 475, 1997.
[5] C. Muthu, M. Ayyanar, N. Raja, and S. Ignacimuthu, "Medicinal plants used by traditional healers in Kancheepuram District of Tamil Nadu, India," Journal of Ethnobiology and Ethnomedicine, vol. 2, article 43, 2006.

[6] A. Togola, D. Diallo, S. Dembélé, H. Barsett, and B. S. Paulsen, "Ethnopharmacological survey of different uses of seven medicinal plants from Mali, (West Africa) in the regions Doila, Kolokani and Siby," Journal of Ethnobiology and Ethnomedicine, vol. 1, article 7, 2005.

[7] G. F. Asprey and P. Thornton, "Medicinal plants of Jamaica," The West Indian Medical Journal, vol. 4, no. 2, pp. 69-82, 1955.

[8] L. M. Giron, V. Freire, A. Alonzo, and A. Caceres, "Ethnobotanical survey of the medicinal flora used by the Caribs of Guatemala," Journal of Ethnopharmacology, vol. 34, no. 2-3, pp. 173-187, 1991.

[9] S. Duttagupta and P. C. Dutta, "Pharmacognostic study of the leaf of Heliotropium indicum," Journal of Crude Drug Research, vol. 15, pp. 141-151, 1977.

[10] E. Quisumbing, "Medicinal Plants of Phillipines," Tech. Rep. 16, Department of Agriculture and Natural Resources, Technical Bulletin, Manila, Philippines, 1951.

[11] J. Berhault, Floore Illustree du Senegal. Govt. Senegal, Min Rural Development, Water and Forest Division, Dakar, Senegal, 1974.

[12] N. Nagaraju and K. N. Rao, "A survey of plant crude drugs of Rayalaseema, Andhra Pradesh, India," Journal of Ethnopharmacology, vol. 29, no. 2, pp. 137-158, 1990.

[13] B. Barrett, "Medicinal plants of Nicaragua's Atlantic Coast," Economic Botany, vol. 48, no. 1, pp. 8-20, 1994.

[14] M. Misawa, M. Hayashi, and S. Takayama, "Production of antineoplastic agents by plant tissue cultures. I. Induction of callus tissues and detection of the agents in cultured cells," Planta Medica, vol. 49, no. 2, pp. 115-119, 1983.

[15] M. S. Hoque, A. Ghani, and H. Rashid, "Alkaloids of Heliotropium indicum Linn. Grown in Bangladesh," Bangladesh Pharmaceutical Journal, vol. 5, no. 3, pp. 13-15, 1976.

[16] F. R. Medina and R. Woodbury, "Terrestrial plants Molluscicial to Lymnacid host of Fascilisis hepatica in Puertorico," Journal of Agriculture of the University of Puerto Rico, vol. 63, pp. 366376, 1979.

[17] J. J. Willaman and H. Li, "Alkaloid bearing plants and their contents alkaloids," Loydia, vol. 33, no. 1, pp. 1-286, 1968.

[18] H. Birecka, T. E. Dinolfo, W. B. Martin, and M. W. Frohlich, "Polyamines and leaf senescence in pyrrolizidine alkaloidbearing Heliotropium plants," Phytochemistry, vol. 23, no. 5, pp. 991-997, 1984.

[19] S. Duttagupta and P.C. Dutta, "Pharmacognostic study of the leaf of H. indicum," Journal of Crude Drug Research, vol. 1, no. 5, p. 141, 1998.

[20] G. F. Asprey and P. Thornton, "Medicinal plants of Jamaica," The West Indian Medical Journal, vol. 4, no. 2, pp. 69-82, 1955.

[21] A. O. Ogunbinu, G. Flamini, P. L. Cioni, M. A. Adebayo, and I. A. Ogunwande, "Constituents of Cajanus cajan (L.) Millsp., Moringa oleifera Lam., Heliotropium indicum L. and Bidens pilosa L. from Nigeria," Natural Product Communications, vol. 4, no. 4, pp. 573-578, 2009.

[22] C. K. Andhiwal, C. Has, and R. P. Vershney, "Chemical and pharmacological studies of H. indicum," Indian Drugs, vol. 22, no. 11 , pp. 567-569, 1981.

[23] M. Kugelman, W. C. Liu, M. Axelrod, T. J. McBride, and K. V. Rao, "Indicine-N-oxide: the antitumor principle of Heliotropium indicum," Lloydia, vol. 39, no. 2-3, pp. 125-128, 1976.

[24] K. Srinivas, M. E. B. Rao, and S. S. Rao, "Anti-inflammatory activity of Heliotropium indicum linn. and Leucas aspera 
spreng. in albino rats," Indian Journal of Pharmacology, vol. 32, no. 1, pp. 37-38, 2000.

[25] G. S. G. Barros, F. J. A. Matos, J. E. V. Vieira, M. P. Sousa, and M. C. Medeiros, "Pharmacological screening of some Brazillian plants," Journal of Pharmacy and Pharmacology, vol. 22, p. 116, 1970.

[26] J. E. V. Vieira, G. S. G. Barros, M. C. Medeiros, F. G. A. Matos, and M. P. Souza, "Pharmacological screening of plants of North East Brazil," Revista Brasileira de Ciências Farmacêuticas, vol. 49, pp. 67-75, 1968.

[27] J. B. Harborne, Phytochemical Methods: A Guide to Modern Techniques of Plant Analysis, Chapman \& Hall, New York, NY, USA, 1984.

[28] H. Wagner and S. Bladt, Plant Drug Analysis, Springer, Berlin, Germany, 1996.

[29] J. J. Morton and M. H. Malone, "Evaluation of vulneray activity by an open wound procedure in rats," Archives Internationales de Pharmacodynamie et de Therapie, vol. 196, no. 1, pp. 117-126, 1972.

[30] J. V. Kamath, A. C. Rana, and A. R. Chowdhury, "Prohealing effect of Cinnamomum zeylanicum bark," Phytotherapy Research, vol. 17, no. 8, pp. 970-972, 2003.

[31] O. H. Lowry, N. J. Rosenbrough, A. L. Farr, and R. J. Randall, "Protein measurement with the Folin phenol reagent," The Journal of Biological Chemistry, vol. 193, no. 1, pp. 265-275, 1951.

[32] H. P. Ehrlich and T. K. Hunt, "The effects of cortisone and anabolic steroids on the tensile strength of healing wounds," Annals of Surgery, vol. 170, no. 2, pp. 203-206, 1969.

[33] K. H. Lee, "Studies on the mechanism of action of salicylates. 3. Effect of vitamin A on the wound healing retardation action of aspirin," Journal of Pharmaceutical Sciences, vol. 57, no. 7, pp. 1238-1240, 1968.

[34] J. S. Reddy, P. R. Rao, and M. S. Reddy, "Wound healing effects of Heliotropium indicum, Plumbago zeylanicum and Acalypha indica in rats," Journal of Ethnopharmacology, vol. 79, no. 2, pp. 249-251, 2002.

[35] S. Nayak, P. Nalabothu, S. Sandiford, V. Bhogadi, and A. Adogwa, "Evaluation of wound healing activity of Allamanda cathartica. L. and Laurus nobilis. L. extracts on rats," BMC Complementary and Alternative Medicine, vol. 6, article 12, 2006.

[36] S. P. Umachigi, K. N. Jayaveera, C. K. Ashok Kumar et al., "Studies on Wound Healing Properties of Quercus infectoria," Tropical Journal of Pharmaceutical Research, vol. 7, pp. 913919, 2008.

[37] A. Abo, J. A. O. Olugbuyiro, and S. A. Famakinde, "Antiinfective and Wound healing properties of Flabellaria paniculata," African Journal of Biomedical Research, vol. 7, pp. 85-87, 2004.

[38] D. C. Odimegwu, E. C. Ibezim, C. O. Esimone, C. S. Nworu, and F. B. C. Okoye, "Wound healing and antibacterial activities of the extract of Dissotis theifolia (Melastomataceae) stem formulated in a simple ointment base," Journal of Medicinal Plants Research, vol. 2, no. 1, pp. 011-016, 2008.

[39] Anonymous, OECD Guidelines for the testing of chemicals, revised draft guidelines 423: acute Oral toxicity- Acute toxic class method, revised document. CPCSEA, Ministry of Social Justice and Empowerment, Govt. of India, 2000.

[40] K. Ilango and V. Chitra, "Wound healing and antioxidant activities of the fruit pulp of Limonia acidissima linn (Rutaceae) in rats," Tropical Journal of Pharmaceutical Research, vol. 9, no. 3, pp. 223-230, 2010.
[41] R. E. Neuman and M. A. Logan, "The determination of hydroxyproline," The Journal of Biological Chemistry, vol. 184, no. 1, pp. 299-306, 1950.

[42] H. P. Misra and I. Fridovich, "The role of superoxide anion in the autoxidation of epinephrine and a simple assay for superoxide dismutase," The Journal of Biological Chemistry, vol. 247, no. 10, pp. 3170-3175, 1972.

[43] H. E. Aebi, Methods of Enzymatic Analysis, Academic Press, New York, NY, USA, 1974.

[44] C. Ya, S. H. Gaffney, T. H. Lilley, and E. Haslam, Chemistry and Significance of Condensed Tannins, Plenum Press, New York, NY, USA, 1988.

[45] H. Tsuchiya, M. Sato, T. Miyazaki et al., "Comparative study on the antibacterial activity of phytochemical flavanones against methicillin-resistant Staphylococcus aureus," Journal of Ethnopharmacology, vol. 50, no. 1, pp. 27-34, 1996.

[46] M. Scortichini and M. P. Rossi, "Preliminary in vitro evaluation of the antimicrobial activity of terpenes and terpenoids towards Erwinia amylovora (Burrill)," Journal of Applied Bacteriology, vol. 71, no. 2, pp. 109-112, 1991.

[47] S. Levine, "The effect of povidone-iodine in controlling skin flora beneath occlusive dressings," Journal of the American Podiatry Association, vol. 60, no. 12, pp. 486-487, 1970.

[48] H. S. Muhammad and S. Muhammad, "The use of Lawsonia inermis linn. (henna) in the management of burn wound infections," African Journal of Biotechnology, vol. 4, no. 9, pp. 934-937, 2005.

[49] M. Getie, T. Gebre-Mariam, R. Rietz, and R. H. H. Neubert, "Evaluation of the release profiles of flavonoids from topical formulations of the crude extract of the leaves of Dodonea viscosa (Sapindaceae)," Pharmazie, vol. 57, no. 5, pp. 320-322, 2002. 

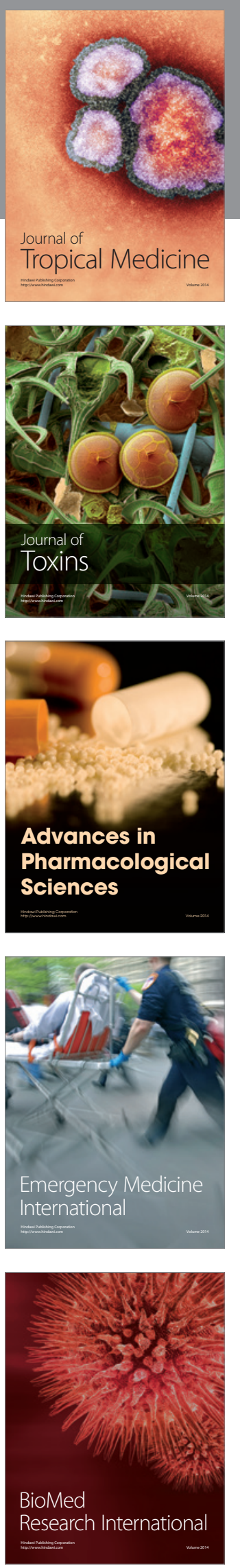
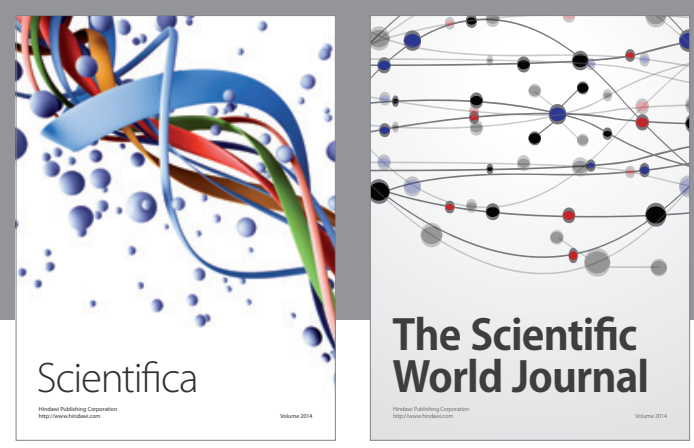

The Scientific World Journal
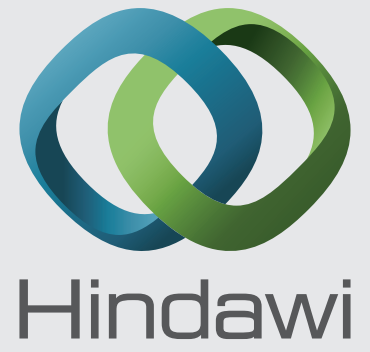

Submit your manuscripts at

http://www.hindawi.com
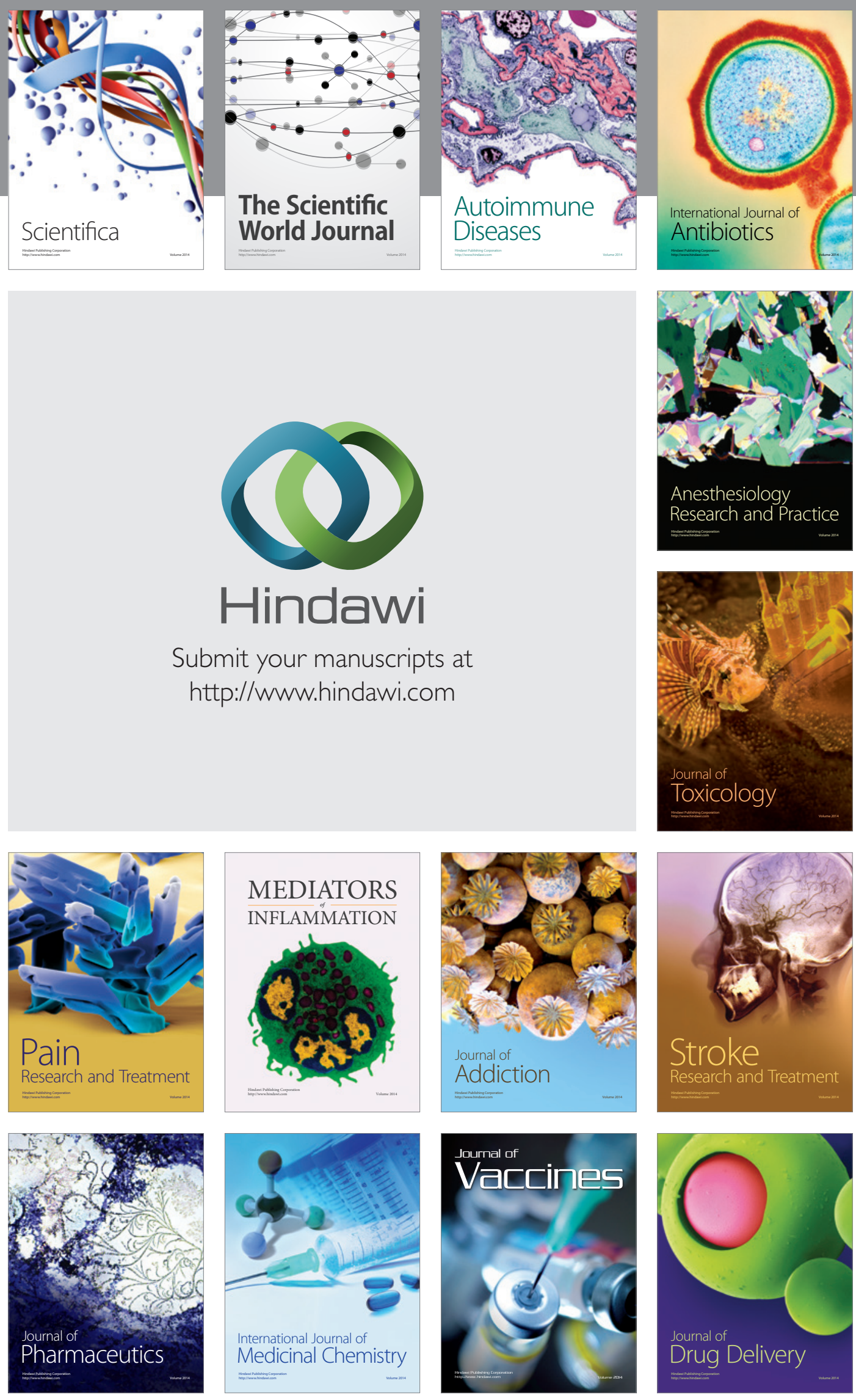